\title{
Corporate Governance Mechanisms and Capital Structure in UAE
}

\author{
Khaled Hussainey* \\ Stirling University \\ and \\ Khaled Aljifri \\ United Arab Emirates University
}

This paper is accepted for publication at Journal of Applied Accounting Research

"Corresponding author: Accounting \& Finance Division, Stirling Management School, University of Stirling, Stirling, FK9 4LA, Scotland, UK. Email: Khaled.Hussainey@stir.ac.uk. 


\title{
Corporate Governance Mechanisms and Capital Structure in UAE
}

\begin{abstract}
Purpose: Our paper aims to contribute to prior research by examining the relation between corporate governance mechanisms and corporate capital structure in one of the emerging economies, United Arab of Emirates (UAE). In particular, we examine the degree to which internal corporate governance mechanisms and an external corporate governance mechanism affect UAE firms' financing decisions.
\end{abstract}

Design/methodology/approach: We use a multiple regression analysis to examine the association between corporate governance and capital structure for a sample of 71 UAE firms listed either in the Dubai financial market or the Abu Dhabi securities market during 2006.

Findings: We find that institutional investors have a negative impact on debt-toequity ratio. This result does not support the 'active monitoring hypotheses where institutional investors are expected to exercise their voting rights effectively in order to prevent managers from reducing their 'employment risk' at the expense of the interests of shareholders. We find no significant association between our measures of the other corporate governance mechanisms and debt-to-equity ratio. We also find that dividend policy is negatively associated with debt-to-equity ratio, while firms' size is positively associated with debt-to-equity ratio.

Research implications: Our study has policy implications for both the UAE stock market and for other emerging economies.

Originality: To the best of our knowledge, there is no study has yet empirically examined the effect of the corporate governance mechanisms on capital structure in UAE or Middle Eastern countries.

Keywords: corporate governance mechanisms, capital structure, dividend policy, emerging economies, UAE. 


\section{Introduction}

Corporate capital structure decisions present a challenge for Accounting and Finance academic researchers. This area of research is well recognized in prior research related to the determinants of corporate capital structure choices. The pioneer paper by Modigliani and Miller (1958) is considered to be the first academic paper to examine this interesting research topic. Modigliani and Miller (1958) show the irrelevance of capital structure decisions for firm value in perfect capital markets. In 1963, they also relax the prefect market assumptions and consider corporate tax in their models (Miller and Modigliani, 1963). Accordingly, they provide new evidence that the firm value will be enhanced if the level of debt increases. Their results suggest that interest is tax deductible, accordingly firms would benefit from debt tax shield when funding their activities by long-term debt. A natural response from academic researchers to these lines of research is to further investigate other drivers of corporate capital structure choices.

Prior research examines the effect of corporate governance internal and external mechanisms on corporate capital structure decisions (see for example Crutchley et al., 1999; Gul, 1999; Wen et al., 2002; Du and Dia, 2005; La Rocca, 2007; Driffield et al., 2007; Al-Najjar and Hussainey, 2009a, 2009b). However, to the best of our knowledge, no study yet has examined the influence of corporate governance on capital structure decisions in United Arab of Emirate (UAE) or Middle Eastern countries. Although this study has specific relevance to the needs of the UAE business environment, it is believed that many other developing countries, especially the Gulf Cooperation Council (GCC) and Middle Eastern countries, share similar social, political and economic environments. The results of this study may be beneficial and applicable to these countries as well. In addition, the results of this 
study may be of interest to policy makers and regulators in other countries with similar socio-economic environments. Consequently, this paper is the first to examine the potential corporate governance internal and external mechanisms that might drive UAE firms to use debt to finance their activities.

The distinctive features of UAE make our study important. For example, Marly and Dillon (2007) argue that, "Western investors have turned to Dubai to establish their regional headquarters while young entrepreneurs are creating firms in this tiny emirate; yet, with Qatar, Bahrain, and Oman establishing similar incentives on paper, why is Dubai still the destination of choice? We argue it is due to three drivers: (1) speed, (2) culture and (3) Governance." Therefore, we believe that studying and determining the association between corporate governance and capital structure is extremely important, especially after the current financial crises, to enhance the efficiency of the UAE market. The results of this study are likely to attract the attention of the UAE policy makers and regulators to some important issues related to corporate governance and capital structure. The UAE has recently initiated the application of international standards of corporate governance attempting to merge with the global economy. By examining the association between internal and external mechanisms of corporate governance and capital structure, the UAE authorities may direct their attention to develop a model of efficiency and a good practice of corporate governance. In addition, determining those factors that have significant effect on capital structure decisions will assist policy makers and regulators to identify situations where efforts should be made to have a healthy association between corporate governance and capital structure.

We find that the capital structure decisions are effected by three variables (i.e., institutional investors, firm size, and dividend payout). The only corporate 
governance variable that is found to have a significant relation with the debt-to-equity ratio is the institutional investors variable. This relation is found to be negative, implying that firms with a high proportion of shares held by institutional investors are less likely to use debt financing. This supports the pecking order theory where firms prefer an internal source of financing (e.g., cash flows from operating activities). The other corporate governance variables (board size, audit type, and governmental investors) and other capital structure theories (i.e., trade off theory, bankruptcy theory, agency theory, and transaction cost theory) are found to have no significant affect on capital structure decisions in the UAE. This is probably because of the different legal, institutional, and cultural factors that shape the influence of corporate governance mechanisms. For example, there is no income tax in the UAE. Therefore, the trade off theory is not applicable. In addition, the corporate governance system is based on large shareholders, as in other developing countries, which makes the agency problem less severe and has only a weak affect on the capital structure decisions.

This paper extends the literature by revealing the impact of selected corporate governance mechanisms (mainly institutional investors and governmental investors) that have not been examined in such an environment and have not been used extensively in other environments. Furthermore, this study enriches the literature by arguing that capital structure theories, in a developing country such as UAE, have limited effect on the capital structure decisions.

The reminder of this paper is organised as follows. In Section 2, we review relevant capital structure theories. Section 3 discusses previous studies on the drivers of corporate capital structure and develops the research hypotheses. Section 4 describes our research method and data. Section 5 presents our empirical findings, and Section 6 concludes and suggests areas for future research. 


\section{Capital structure theories}

Since Modigliani and Miller (1958) capital structure irrelevance propositions, academic researchers have advanced a number of capital structure theories. These theories are extensive and can be classified into two groups: tax-based theories and non-tax based theories. Tax-based theories include both bankruptcy and trade-off theories; while non-tax based theories include agency, signalling, pecking order and transaction cost theories. As United Arab Emirates (UAE) is considered as one of the Arab economies that does not have taxes. We consider both bankruptcy and trade-off theories as irrelevant for the UAE business environment. Therefore, the present paper reviews relevant capital structure theories and attempts to relate the different theoretical attributes to the UAE business environment in order to formulate our research hypotheses. Next subsections will explain these theories.

\subsection{Agency theory}

The agency relation is defined as: " $a$ contract under which one or more persons (the principal(s)) engage another person (the agent) to perform some service on their behalf which involves delegating some decisions making authority to the agent" (Jensen and Meckling, 1976:308). Agency theory looks at the conflicts of interest arising from the possible divergence between the principal (shareholders) and agent (manager) of firms. It is argued that managers have incentives to make investment decisions that reduce their employment risk or increase their compensation (Amihud and Lev, 1981; Baker et al., 1988; Donaldson, 1984). Such agency problems lead to agency costs which are related to monitoring costs and other costs by the agent to assure shareholder that there will be no harm to their interest. 
Based on the agency theory, debt financing can be used as a useful governance device in reducing the conflict of interests between the agent and principal (Jensen, 1986). In particular, debt can serve as a substitute mechanism to reduce the agency costs of free cash flow available to managers by making them disgorge it to investors (Jensen, 1986; Kochhar, 1996).

\subsection{Signalling theory}

Asymmetric information costs exist when only manager possess private information about firm's return opportunities and at the same time shareholder do not have access to this information. Signalling theory suggests that the choice of the firm's capital acts as a signal to outsider investors of the information held by shareholders (Michaelas et al, 1999). This indicates that outsiders will consider any meaningful change in capital structure as a signal for corporate potential performance. The theory assumes that firms should not send any false signals to the market, and consequently investors can differentiate among firms using such signals. The announcement of debt financing may be considered as a positive signal by shareholders. A debt issuance may signal that the firm has good financial prospects that managers do not want additional shareholders to share this potential profit (Ryen et al., 1997; Koch and Shenoy, 1999). In addition, the debt issuance may signal that the firm will be able to pay dividend for current shareholders (Chang and Rhee, 1990)

\subsection{Pecking order theory}

The pecking order theory was developed in two pioneer academic papers (Myers, 1984 and Myers and Majluf, 1984). The theory assumes that firms generally prefer internal to external finance. The theory is based on two practical assumptions 
(Myers, 2001). First, there is an information asymmetry between managers and shareholders. Second, firms would follow a pecking order in their financing, in which managers would prefer an internal source of financing (i.e. cash flows from corporate operations). If the cash flows from corporate operations are insufficient and external funds are required for capital investment, firms will issue the safest security first, this is, debt. Myers (1984) argues that firms would prefer debt financing rather than issuing equity because of lower information costs associated with debt financing. This leads to an increase in the debt-to-equity ratio. If there is a requirement of further external financing, firms work down from safe to riskier debt, perhaps convertible securities or preferred stock are used first, and when it is not reasonable to use more debt then equity will be the last option.

\subsection{Transaction cost theory}

Transaction cost theory mainly was developed by Coase (1937). Kochhar (1996:715) explains that, "transaction cost economies is concerned with the governance of contractual relations in transactions between two parties (Coase, 1937; Williamson, 1975, 1985)". Each governance structure is associated with different levels of transaction costs. These include "costs arise from the setup and running costs of the governance structures, as well as other costs, such as those due to renegotiation, that arise from a shift in the alignment" (Kochhar, 1996:715). He argues that transactions costs and benefits associated with different sources of finance are not the same. For example, although debt holders can push the firm into bankruptcy if the firm fails to meet its contractual obligations (i.e. repaying the principal and the interest), they have little control over managerial actions in ensuring that resources are efficiently used. On the other hand, the equity holders have control over managerial actions (i.e. they can monitor and evaluate managerial actions continuously). In 
addition, equity possesses stronger governance abilities than the debt instrument (Kochhar, 1996) and then transactions costs for equity issuance is usually higher than transaction costs for debt issuance. Furthermore, it is well known that large firms tend to have more transactions in the stock market compared with small firms. Therefore this theory predicts that transaction costs of large firms are more likely to be lower than transaction costs for small firms. Hence, large (small) firms are expected to use more (less) equity financing than debt financing.

\section{Related Literature and Research Hypotheses}

\section{Related Literature}

In this paper, we evaluate whether a UAE firm's capital structure decisions are affected by internal and external corporate governance mechanisms. Prior research suggests firm characteristics and corporate governance mechanisms that potentially drive the capital structure decisions. In Section 2, we discussed the main theories of capital structure decisions. In this section, we review relevant empirical research that investigates the degree to which the above theories explain firm's capital structure decisions in the UAE.

Prior research suggests several factors that affect firms' decisions in choosing their capital structure. The work of Titman and Wessels (1988) is considered to be a landmark study of the determinants of capital structure. They find that firm's size and profitability are negatively associated with the debt-to-equity ratio, while firm's asset tangibility is positively associated with the debt-to-equity ratio. These findings are consistent with transaction cost theory, pecking order theory, and agency theory. Similarly, Rajan and Zingales (1995) investigate the determinants of capital structure in major industrialised countries. They find that the market-to-book ratio of assets and 
profitability ratio are negatively associated with the debt-to-equity ratio, while asset tangibility and firm's size are positively related to the debt-to-equity ratio. These results are consistent with pecking order theory, bankruptcy theory, and agency theory. However, the negative relationship between the market-to-book ratio of assets and the debt-to-equity ratio is inconsistent with agency theory.

In addition, in a seminal empirical study, Delcoure (2007) examines the determinants of capital structure choices in a sample of Central and Eastern European countries. The author finds that asset tangibility is positively associated with capital structure choices and this finding is consistent with agency theory. Consistent with the pecking order theory the study also shows a negative association between profitability and capital structure choice.

The above empirical research shows that there are 'core' firm characteristics determinants of capital structure choices, however, these papers do not take into account corporate governance internal and external mechanisms.

In prior research, there is strong evidence that internal and external mechanisms of corporate governance affect corporate capital structure decisions (Crutchley et al., 1999; Gul, 1999; Wen et al., 2002; Du and Dia, 2005; La Rocca, 2007; Driffield et al., 2007; Al-Najjar and Hussainey, 2009a, 2009b). Although the relation between corporate governance and capital structure has been the subject of extensive research in developed countries, limited research has been carried out to investigate the issue in business environment of developing countries and even fewer such studies may be found in the Middle Eastern countries. Therefore, we are aiming to answer the following research question: What drives the capital structure decisions of UAE listed firms? We are particularly interested to know whether corporate governance affects the capital structure choices for firms listed in Dubai financial 
market or the Abu Dhabi securities market. In the subsequent paragraphs we discuss the formulation of our research hypotheses.

\section{Research Hypotheses}

\section{Internal Corporate Governance Mechanisms}

Board Size: The board of directors is responsible for managing firm's activities and making strategic decisions (i.e. the optimal capital structure mix). The relation between the number of directors on boards and corporate capital structure choices has been well established in prior accounting and finance research (see for example Mehran, 1992; Berger et al., 1997, Wiwattanakantang, 1999, Wen et al., 2002, Du and Dia, 2005, Abor and Biekpe, 2005, and Al-Najjar and Hussainey, 2009a and 2009b. However, the empirical evidence on direction of the association between board size and capital structure is mixed.

Mehran (1992), Berger et al. (1997), and Abor and Biekpe (2005) find that there is a significant negative association between board size and debt-to-equity ratio. This means that firms with larger board of directors generally have low debt-equity ratios. Berger et al. (1997) argue that larger boards exert pressure on managers to follow lower debt-to-equity ratio and enhance firm performance.

On the other hand, a positive and statistically significant relation is found in Jensen (1986). This positive sign indicates that firms with larger board size are more likely to use more debt to finance their activities than equity. Other researchers find no statistically significant relation between board size and debt-to-equity ratio (Wiwattanakantang, 1999; Wen et al., 2002; Al-Najjar and Hussainey, 2009a). Wen et al. (2002) argue that firms with large boards are more likely to follow a policy of higher levels of debt-equity ratios to enhance firm value especially when these are 
entrenched due to greater monitoring by regulatory authorities. They also argue that larger board may find it difficult to reach a consensus in decisions which can ultimately affect corporate governance quality of a particular firm (i.e. increasing agency costs). Hence, debt issuance is more likely to be used as a governance mechanism to reduce the conflict of interests between the agents and principals by reducing the agency costs of free cash flow available to managers (Jensen, 1986; Kochhar, 1996).

In UAE, large firms are more likely to have large board size. Large firms with large board size are expected to be profitable and have less potential for bankruptcy compared with small firms. Because of UAE and culture-related issues, it is extremely difficult to reach a consensus in decisions especially in a UAE economic system and this might lead to increase agency costs and reduce firm performance (Aljifri and Moustafa, 2007). Additionally, Anderson et al. (2004) argue that the cost of debt is generally lower for firms with large number of directors on their board. Therefore, we expect that UAE firms with higher board size will use debt issuance rather than equity issuance to finance their activities. This should reduce agency costs for these firms. Thus our first hypothesis is:

H1: Ceteris paribus, there is a positive relation between board size and the debt-to-equity ratio.

Institutional Investors: The relation between institutional investors and corporate capital structure decisions has received little attention in prior research. Jensen (1986) argues that this type of investors can reduce the agency costs by monitoring the corporate performance and by ensuring the shareholders' interests. In addition, Shleifer and Vishny (1986) offer evidence that these investors monitor management team's performance effectively. 
Lev (1988) argues that the institutional investors are well informed compared with individual investors. This is due to the fact that institutional investors have easy access to different sources of information. As a result, Lakshmi (2009:2) argues that:

"The close monitoring of institutional investors may force managers to take decisions in the interests of shareholders. Their ability to purse self interests may diminish. As a result, managers may be prevented from employing lower levels of debt to protect their employment risk".

Crutchley et al. (1999) provide evidence that the association between institutional investors and the debt-to-equity ratio is positive and statistically significant. This leads us to set the second research hypothesis for the impact of institutional investors on the capital structure choices as follows:

H2: Ceteris paribus, there is a positive relationship between institutional investors and the debt-to-equity ratio.

Governmental Ownership: Prior research offers empirical evidence that the association between governmental ownership and debt financing is positive and statistically significant (Gul, 1999). Similar to the effect of institutional investors, we expect that government will force corporate managers to take decisions in the interests of shareholders. Consequently, corporate managers will potentially avoid choosing lower levels of debt to guard their employment risk. Based on the empirical evidence of Gul (1999), we expect a positive relationship between governmental ownership and the debt-to-equity ratio. Therefore, we set the third research hypothesis for the impact of governmental ownership on the capital structure choices as follows:

H3: Ceteris paribus, there is a positive relationship between governmental ownership and the debt-to-equity ratio. 


\section{An External Corporate Governance Mechanism}

A number of relatively new articles have investigated the association between asymmetric information and corporate financial decisions (see Li and Zhao, 2006 for more details). In a recent study, Bharath et al. (2009) use a new information asymmetry index and study the degree of information asymmetry is considered as one of the determinants of corporate capital structure decisions. They contributed to accounting and finance literature by offering the first evidence that asymmetric information drives the capital structure decisions of US firms. In particular, they find a positive relationship between their measure of asymmetric information and the debtto-equity ratio. In other words, their findings show that US firms with higher levels of information asymmetric are more likely to use debt in financing their activities than equity. Based on the above results, we investigate the role of the information environment on the capital structure decisions for a sample of UAE listed firms. We use audit type as a measure of the firm's information environment. Prior research finds that audit type is negatively associated with asymmetric information. For example, Lee et al. (2007) and Hussainey (2009) offer evidence that when financial statements are audited by big 4 firms, the levels of corporate information asymmetry between the firm and investors are reduced and hence investors can better anticipate future earnings in the stock market. Based on these arguments and empirical evidence, we set the following fourth research hypothesis for the impact of audit type (as a proxy for asymmetric information) on capital structure decisions:

H4: Ceteris paribus, there is a negative relationship between audit type and the debtto-equity ratio. 


\section{Research Method and Data}

\section{Research Method}

With the aim of examining the association between corporate governance internal and external mechanisms and corporate capital structure decisions, we regress the debt-to-equity ratio on some corporate governance mechanisms and some control variables. We use the following model to test our research hypotheses:

$$
\operatorname{Lev}_{i t}=\alpha+\beta^{\prime} X_{i t}+\varepsilon_{i t}
$$

Where:

$L e v_{i t}$ is our measure of the capital structure decisions which is defined as debt to equity ratio; $\alpha$ is the intercept. $\beta^{\prime}$ is the slope coefficient estimates of regressors. $X_{i t}$ is the corporate governance variables (i.e. board size, institutional investors, governmental ownership and audit type) and for firm i at time t. Our dependent and independent variables are defined in Table (1).

We also include four control variables in our regression model. These include Tobin's $\mathrm{Q}$, profitability, firm size and dividend policy. Tobin's Q is used in prior research as a proxy for growth opportunity. For example, Shyam-Sunder and Myers (1999) find that corporate growth opportunity is negatively associated with the debt-to-equity ratio. This result is consistent with the theoretical prediction of the trade-off theory. In addition, Profitable firms are likely to have more retained earnings. Therefore, based on the pecking order theory, profitable firms would prefer internal financing sources over the external sources. So a negative association between profitability and the debt-to-equity ratio is found in prior research (i.e. Kayhan and Titman, 2007). Furthermore, it is argued that large firms are more mature firms; and less likely to 
bankrupt because of lower default risk than smaller firms (Elsas and Florysiak, 2008). Additionally, because of economies of scale, these firms face relatively lower cost per monetary unit raised externally. As a result, prior research finds that large firms are more likely to finance their activities using debt than smaller firms (Al-Najjar and Hussainey, 2009a and 2009b). Finally, prior research found a negative relationship between dividend policy and capital structure. In particular, Jensen et al., (1992) and Aivazian et al., (2003) among those who argued that a firm's debt-to-equity ratio is a key factor explaining the firm's decisions to pay dividend. This result is supported by the agency costs theory of dividend policy. On the other hand, Chang and Rhee (1990) offered evidence showing a positive relationship between debt-to-equity ratio and corporate dividend policy, suggesting that "Firms with high payout ratios tend to be debt financed, while firms with low payout ratios tend to be equity financed" (p. 23). This result is supported by the signalling theory. Our control variables are defined in Table 1.

\section{Sample Selection and Data Collection}

All sample firms are listed in either the Dubai Financial Market or Abu Dhabi Securities Market; the choice of firms was based on the availability of data. The year 2006 was selected as it was the most recent data available at the time of the study. A time series analysis is not conducted in this study because of the high cost and the substantial effort needed to collect the data manually, especially the data related to corporate governance variables. Another important reason for not conducting a time series analysis is that the nature of the corporate governance mechanisms used in this study does not change over a short time of period, which alleviates the time-specific effects in this study. A total of 117 listed firms were incorporated at the time of the study. The banking and insurance sectors (46 firms) were excluded from the sample 
as they are more regulated and have different capital structure mechanisms. Consequently, only 71 corporate annual reports were collected representing approximately $61 \%$ of the total population and $100 \%$ of the total of the non-financial firms (see Table 2). The sample includes firms which are dissimilar in size, and sector.

\section{Empirical Results}

\section{Descriptive Analysis}

Table 3 reports the minimum, maximum, mean and standard deviation for the continuous variables in the sample data of this study. A broad range of variation is evident in the sample. The table provides some information about debt equity, which ranges from 0.00 to 6.83 and has a mean of 0.36 and a standard deviation of 0.97 . This indicates that UAE firms, on average, do not have high gearing. Firm size (logarithm of revenues) ranges from 7 to 21 with a mean of 13.19 and a standard deviation of 2.09. Profitability ranges from 0.01 to 0.93 with a mean of 0.32 and a standard deviation of 0.24 . This means that UAE firms, on average, have high profitability. The institutional investor ratio ranges from 0.00 to 0.99 with a mean of 0.30 and a standard deviation of 0.23 . Taking the average, it seems that UAE firms having reasonable percentage of institutional investors. In relation to board size, the results reveal a range from 3 to 15 with a mean of 7 and a standard deviation of 2.18. The governmental investor ratio ranges from 0.00 to 0.80 with a mean of .11 and a standard deviation of 0.19 . This indicates that governmental investors participate less in the ownership of UAE firms than institutional investors. The dividends payout ratio ranges from 0.00 to 0.96 with a mean of 0.26 and a standard deviation of 0.27 . This result is to be expected, as a new and growing market may use a high dividend payout ratio to help attracting more investors and increase firm value. The Tobin $\mathrm{Q}$ ranges 
from 0.02 to 3.16 with a mean of 1.33 and a standard deviation of 0.61 . The table also provides some information about the characteristics of the sample. It reveals that there is no statistically significant difference between the performance of firms engaging with the Big 4 accountancy firms and firms engaging with other auditing firms.

\section{Regression Analysis}

Table 4 shows that the coefficient of determination $\left(\mathrm{R}^{2}\right)$ is equal to 32 percent and the adjusted $\mathrm{R}^{2}$ is equal to 18 percent which means that a considerable proportion of the variance is accounted for. The table also shows that the model reaches statistical significance as the p-value is less than 0.05 .

Tolerance values are calculated using $\left(1-\mathrm{R}^{2}\right)$ for each variable and are presented in Table 4. Since all values are more than 0.10 , there is no issue of multicolinearity between the independent variables (Menard, 1995). Also, all of the variance inflation factors (VIF) for the independent variables are less than 10 , suggesting that there is no multi-colinearity between these variables (Myers, 1990).

Table 5 presents the beta coefficients for the independent variables. The $t$ statistics with the largest absolute values are 3.366 (p-value $<0.01),-2.884$ (p-value $<$ 0.01 ), and -2.259 ( $\mathrm{p}$-value $<0.05$ ), which relate to firm size, dividends payout ratio, and institutional investors ratio respectively. This indicates that the three variables have a comparable degree of importance in the model. In other words, they make the strongest unique contribution to explaining capital structure determination.

The variable of institutional investors has a negative effect on capital structure. In other words, this result shows that firms that have a large proportion of institutional investors have less debt to finance. This result does not support the "active monitoring 
hypothesis" of Demsetz (1983) and Shleifer and Vishny (1986) where institutional investors are expected to exercise their voting rights effectively in order to prevent managers form reducing their "employment risk" at the expense of the interests of shareholders. On the other hand, the result is consistent with the results of Pound (1988) who suggests that there is a strategic alignment of mangers and institutional investors.

The model shows that the dividends payout ratio has a significant negative impact on capital structure. This result supports the theoretical expectation regarding the disciplining role of dividend payouts. However, it contradicts the findings of Bohren and Odegaard (2003), who found no disciplining role of dividend payouts. This result can be interpreted in another way, and it can be argued that a firm with a high payout ratio is more likely to use up its opportunity to reinvest for future growth. In other words, the higher the dividends payout ratio, the less the retained earnings, and hence the more debt a firm may need. Then the question is why the relationship between the payout of dividends and capital structure is negative. One possible interpretation for this result is that paying out more dividends exposes firms to more monitoring. Moreover, higher payout can limit management discretion over free cash flow. Therefore, a negative impact is expected for the dividends payout ratio on debtto-equity ratio.

Firm size is found to have a positive significant impact on capital structure. This is in agreement with the findings of Klapper and Love (2003), Bohren and Odegaard (2003), and Larker et al. (2004). This result may reflect an independent source of value creation, possibly due to market power and economies of scale and scope (Bohren \& Odegaard, 2003). In addition, large firms in the UAE have more resources (e.g., more skilled managers) compared to medium and small firms, and this 
may help them to be more efficient and attractive to lenders. This indicates that large firms in the UAE tend to be more diverse in their debt management, and less likely to go bankrupt. Moreover, these firms are more likely to have a relatively lower cost for debt raised externally because of economies of scale (i.e. raising larger amounts of external finance).

At the same time, the corporate governance variables, government ownership, audit type, and board size, were found not to have a significant impact on capital structure. This result may be interpreted as indicating that the effective application of the appropriate principles and standards of corporate governance is absent in listed firms in the UAE. However, the government ownership has a negative impact on capital structure, although this result in not statistically significant. This result supports the 'active monitoring hypothesis' of Demsetz (1983) and Shleifer and Vishny (1986) among others, and contradicts the results of Larcker et al. (2004) and Jong et al. (2005). The audit type variable has no significant effect on capital structure and that is probably because of the high quality of all the audit firms, including the small ones. Aljifri (2008) examines the level of financial disclosure by UAE listed firms in 2003 and finds that there is no significant difference in the disclosure levels between firms engaging with the big four audit firms and firms engaging with other audit firms. In other words, the audit type (by large or small firms) does not affect capital structure in UAE firms. The results also reveal that board size has a negative impact, although not significant, on capital structure. This suggests that UAE firms, on average, may select board members who are more conservative in relation to financial risk. 


\section{Conclusion}

This study concludes that three variables appear to be strong predictors of the capital structure adopted by firms in the UAE. However, another five variables (including control variables) are found to have a weak effect on the capital structure which could be a result of the absence of some important aspects of corporate governance practices and a lack of enforcement of rules.

The central conclusions from our empirical analysis suggest that the financing decisions of UAE firms are driven by three variables (i.e., institutional investors, firm size, and dividend payout). The proportion of ordinary shares held by the institutional investors is the only corporate governance variable found to have a statistically significant relation with debt-to-equity ratio. This relation is found to be negative which implies that firms who have a large proportion of institutional investors are less likely to meet their financing needs by using debt. This behaviour is compatible with the pecking order theory, according to which firms would prefer to use internal sources of financing, such as cash from operating activities. The other corporate governance variables (board size, audit type, and governmental investors) and other capital structure theories (i.e., trade off theory; bankruptcy theory; agency theory; and transaction theory) are found not to have a significant effect on capital structure decisions made by UAE firms. The fact that these variables, many of which have been found to be significant in other markets, are not significant in the UAE may be because different legal, institutional, and cultural factors operate in the UAE. Those factors may shape the way in which corporate governing mechanisms influence capital structure decisions. For example, there is no income tax in the UAE, and this will mean that mechanisms that are used to trade off taxes against profits will not be relevant in the UAE. In addition, the corporate governance system in the UAE is 
based on the presence of large shareholders, as it is in many other developing countries. Market that is dominated by large shareholders may have less severe agency problems than would otherwise be the case, and agency theory may be of less use in examining capital structure decisions.

Our paper shows that there is negative association, though not statistically significant, between UAE firms' profitability and their debt-to-equity ratio. This finding is consistent with the pecking order theory which suggests that firms would follow a financing pattern that ranked different sources of finance in a particular order. They would prefer internal financing sources (e.g. retained earnings) over the external sources. Profitable firms are likely to have more retained earnings. Hence there firms are less likely to finance their activities by debt.

Finally, we find that there is a negative association, though not statistically significant, between board size and debt-to-equity ratio for UAE firms. This result suggests that boards with a large number of directors are more likely to have difficulty in reaching agreement because of different and conflicting opinions and views. Consequently, UAE firms with large boards prefer equity financing rather than debt financing to reduce the cost associated with communication and coordination problems between directors. Additionally, the result suggests that UAE directors might prefer equity financing because their firms have, on average, healthy profitability.

It is hoped that this study will improve the understanding of corporate governance mechanisms and their impact on the capital structure decisions. The study extends the literature on the effect of firm-specific variables on capital structure 
decisions in the UAE. This may help users of financial information to assess the impact of such variables in improving capital structure decisions.

This study indicates that there may be a need to encourage policy makers in the UAE to ensure that firms implement effective internal and external corporate governance mechanisms. This implementation should be appropriate for the UAE business environment while embracing international corporate governance standards. It is expected that the effective implementation of the codes of corporate governance will contribute to improve efficiency, effectiveness and governance in the UAE stock markets. Therefore, a real commitment is needed from all listed firms in the market, and this can only be achieved by improving the regulatory and enforcement frameworks.

Future research should be conducted taking into account some important corporate governance variables such as the level of ownership concentration, the percentage of outside board members, the existence of an audit committee, insider ownership, voting coalitions, product-market competition, and other hidden cultural factors. Additional research might also be directed towards the effect of corporate governance mechanisms on the capital structure decisions of UAE firms using larger samples and longer time series. 


\section{References}

Abor, J. and Biekpe, N. (2005). "Does corporate governance affect the capital structure decision of Ghanaian SMEs?", Working paper, University of Stellenbosch Business School.

Aivazian, V., Booth, 1. and Cleary, S. (2003), "Do emerging market firms follow different dividend policies from U.S. firms? ", Journal of Financial Research, Vol. 26 No. 3, pp. 371-387.

Al-Najjar, B. and Hussainey, K. (2009a). "What drives firms' capital structure and dividend policy?", Working paper, Middlesex University, UK.

Al-Najjar, B. and Hussainey, K. (2009b). "Revisiting the capital structure puzzle: UK evidence", Working paper, Middlesex University, UK.

Aljifri, K. \& Moustafa, M. (2007). "The Impact of Corporate Governance Mechanisms on the Performance of UAE Firms: An Empirical Analysis", Journal of Economics \& Administrative Science, Volume 23 (2), 72-93.

Aljifri, K., (2008). "Annual reports disclosure in a developing country: the case of UAE", Advances in Accounting, Volume 24, (1), 93-100.

Amihud, Y. and Lev, B. (1981). "Risk reduction as a managerial motive for conglomerate mergers", Bell Journal of Economics, 12, 605-616.

Anderson R., Mansi, S. and Reeb, D. (2004). "Board characteristics, accounting report integrity and the cost of debt", Journal of Accounting and Economics, 37, 315342.

Baker, G.P., Jensen, M. C. and Murphy, K. J. (1988). "Compensation and incentives: practice vs. theory", Journal of Finance, 43, 593-615.

Berger, P.G., Ofek, E., Yermack, D.L., (1997). "Managerial entrenchment and capital structure decision”. Journal of Finance, 52, 1411-1438.

Bharath, S., Pasquariello, P. and Wu, G. (2009). "Does asymmetric information drive capital structure decisions?", Review of Financial Studies, forthcoming.

Bohren, O., and Odegaard, B. (2003). "Governance and performance revisited. ECGI", working paper No. 28.

Chang, R. P. and Rhee, S. G. (1990), "The impact of personal taxes on corporate dividend policy and capital structure decisions", Financial Management, Vol. 19 No. $2,21-31$.

Coase, R. (1937). "The nature of the firm", Economica 4 (16): 386-405 
Crutchley, C., Jensen, M., Jahera, J., and Raymond, J. (1999). "Agency problem and the simultaneity of financial decision making: the role of institutional ownership", International Review of Financial analysis, 8, 177-197.

Delcoure N. (2007). "The determinants of capital structure in transitional economies", Journal of International Review of Economics and Finance, 16: 400-415.

Demsetz, H. (1983, June). "The structure of the ownership and the theory of the firm". Journal of Law and Economics, 375- 390.

Donaldson, G. (1984). Managing Corporate Wealth. Praeger, New York.

Driffield, N., Mahambare, V. and Pal, S. (2007). "How does ownership structure affect capital structure and firm value". Economics of Transition, 15 (3), 535-537.

Du, J. and Dai, Y. (2005). "Ultimate corporate ownership structure and capital structures: evidence from East Asian economies", Corporate Governance, 13 (1): 6071.

Elsas, R. and Florysiak, D. (2008). "Empirical capital structure research: new ideas, recent evidence and methodological issues", Working Paper, University of Munich.

Gul, F.A. (1999). "Government share ownership, investment opportunity set and corporate policy choices in China", Pacific-Basin Finance Journal 7 (2): $157-172$.

Huang S.G. Song, F.M. (2006). "The determinants of capital structure: evidence from China", China Economic Review, 17: 1-23.

Hussainey, K. (2009). "The impact of audit quality on earnings predictability", Managerial Auditing Journal, 24 (4): 340-351

Jensen M.C. (1986), "Agency costs of free cash flow, corporate finance, and takeovers", American Economic Review, 76: 323-329.

Jensen M. Meckling W. (1976). "The theory of the firm: managerial behaviour, agency costs, and ownership structure", Journal of Financial Economics, 3(4): 305360 .

Jensen, G., Solberg, D., and Zorn, T. (1992), "Simultaneous determination of insider ownership, debt, and dividend policies ", Journal of Financial and Quantitative Analysis, Vol. 27, 247-263.

Jong, A., DeJong, D., Mertens, G., \& Wasley, C. (2005). "The role of self-regulation in corporate governance: evidence and implications from the Netherlands". Journal of Corporate Finance, 11 (3), 473-503.

Jong, A., Kabir, R. and Nguyen, T. (2008). "Capital structure around the world: the roles of firm- and country-specific determinants", Journal of Banking \& Finance, 32, 1954-1969. 
Kayhan, A, Titman, S. (2007). "Firms' histories and their capital structures", Journal of Financial Economics, 83(1), 1-32.

Klapper, L., \& Love, I. (2003). "Corporate governance, investor protection and performance in emerging markets". Journal of Corporate Finance, 1-26.

Koch P.D. Shenoy C. (1999). "The information content of dividend and capital structure policies", Financial Management, 28(4): 16-35.

Kochhar, R. (1996). "Explaining firm capital structure: the role of agency theory vs. transaction cost economies", Strategic Management Journal, 17, 713-728.

La Rocca, M. (2007). "The influence of corporate governance on the relation between capital structure and value", Corporate Governance, 7 (3), 312-325.

Lakshmi, K. (2009). "Ownership structure and capital structure: evidence from Indian firms". Working paper, http://ssrn.com/abstract=1344113

Larcker, D., Richardson, S., \& Tuna, I. (2004). "How important is corporate governance". SSRN, working paper, series No. 595821.

Lee, B. B., Cox, S. and Roden, D. (2007). "Have the big accounting firms lost their audit quality advantage: evidence from the returns-earnings relation", Journal of Forensic Accounting, Vol. VIII, 271-286.

Lev, B. (1988). "Toward a theory of equitable and efficient accounting policy", The Accounting Review, 63, 1-21.

Li, K. and Zhao, X. (2008). "Asymmetric information and dividend policy", Financial Management, 37 (4), 673-694.

Matly, M. and Dilon, L. (2007). "Dubai strategy: past, present, future", Belfer Center for science and International Affairs, John F. Kennedy School of Government, Harvard University.

Mehran, H. (1992). "Executive incentive plans, corporate control, and capital structure". Journal of Financial and Quantitative Analysis, 27, 539-560.

Menard, S. (1995). "Applied logistic regression analysis". Sage University Paper Series on Quantitative Applications in the Social Sciences. Thousands Oaks, CA: Sage.

Michaelas, N., Chittenden, F. And Poutziouris, P. (1999). "Financial policy and capital structure choice in U.K. SMEs: empirical evidence from company panel data", Small Business Economics, 12, 113-130.

Miller, M., Modigliani, F. (1963). "Corporate income taxes and the cost of capital: a correction". American Economic Review, 53 (3): 433-443. 
Modigliani, F.; Miller, M. (1958). "The cost of capital, corporation finance and the theory of investment". American Economic Review, 48 (3): 261-297.

Myers S.C. (1984). "The capital structure puzzle", Journal of Finance, 39(3): 575592.

Myers, R. (1990). Classical and Modern Regression with Applications. Boston, MA: Duxbury.

Myers, S. (2001). "Capital structure", Journal of Economic Perspectives, 15(2),81102.

Myers S.C. Majluf, N.S. (1984). "Corporate financing and investment decisions when firms have information that investors do not have", Journal of Financial Economics, 13: $187-221$.

Rajan R.G. and Zingales, L. (1995). "What do we know about capital structure? some evidence from international data", Journal of Finance, 50(5): 1421-1460.

Ryen G.T., Vasconcellos G.M. and Kish R.J. (1997). "Capital structure decisions: what have we learned?", Business Horizon, 40(5): 41-50.

Shleifer, A., and Vishny, R. (1986). "Large shareholders and corporate control", Journal of Political Economy, 94, 462-488.

Shyam-Sunder, L. and Myers, S.C. (1999). "Testing static trade-off against pecking order models of capital structure". Journal of Financial Economics, 51(2), 219-244.

Titman, S. and Wessels, R. (1988). "The determinants of capital structure choice". Journal of Finance, 43(1): 1-19.

Wen, Y., Rwegasira, K. and Bilderbeek, J. (2002). "Corporate governance and capital structure decisions of the Chinese listed firms", Corporate Governance, 10 (2), 75-83.

Williamson, O.E. (1975). Markets and Hierarchies. Free Press, New York.

Williamson, O.E. (1985). The Economic Institutions of Capitalism. Free Press, New York.

Wiwattanakantang, Y. (1999). "An empirical study on the determinants of the capital structure of Thai firms", Pacific-Basin Finance Journal, 7, 371-403. 
Table 1 Definition of variables

\begin{tabular}{|l|l|}
\hline \multicolumn{1}{|c|}{ Variable } & \multicolumn{1}{c|}{ Definition } \\
\hline Leverage $\left(L e v_{i t}\right)$ & $\begin{array}{l}\text { Debt to equity ratio } \\
\text { The number of executive and } \\
\text { non executive directors on the board. }\end{array}$ \\
\hline Board size & $\begin{array}{l}\text { The proportion of the ordinary shares held by the } \\
\text { institutional investors. }\end{array}$ \\
\hline Institutional investors & $\begin{array}{l}\text { The proportion of ordinary shares owned by the } \\
\text { government. }\end{array}$ \\
\hline Audit type & $\begin{array}{l}\text { A dummy variable and takes the value of one if the } \\
\text { audit firm is one of the Big 4 and zero otherwise }\end{array}$ \\
\hline Tobin's Q & $\begin{array}{l}\text { The market value of equity plus the book value of } \\
\text { the debt divided by the book value of the total } \\
\text { assets. }\end{array}$ \\
\hline Profitability & Net income divided by sales \\
\hline Firm size & The natural logarithm of sales \\
\hline Dividend policy & Dividend Payout ratio \\
\hline
\end{tabular}

Table 2 Sample Selection

\begin{tabular}{|c|c|}
\hline Sectors & No. of Firms \\
\hline All sectors* & 117 \\
\hline Banking and insurance sectors & 46 \\
\hline The study sample & 71 \\
\hline
\end{tabular}

The Abu Dhabi Securities Market and Dubai Financial Market use different sector classifications which make determining the number of firms in each sector difficult and not accurate. 
Table 3 Descriptive Statistics

\begin{tabular}{|l|c|c|c|c|c|}
\hline & $\mathbf{N}$ & Minimum & Maximum & Mean & $\begin{array}{c}\text { Std. } \\
\text { Deviation }\end{array}$ \\
\hline Debt Equity & 71 & .00 & 6.83 & .36 & 0.97 \\
\hline Board size & 71 & 3.00 & 15.00 & 7.00 & 2.18 \\
\hline Institutional Investors & 71 & 0.00 & 0.99 & 0.30 & .023 \\
\hline $\begin{array}{l}\text { Governmental } \\
\text { ownership }\end{array}$ & 71 & 0.00 & 0.80 & 0.11 & 0.19 \\
\hline Audit Type- Big 4** & 41 & 0.00 & 6.83 & 0.42 & 1.13 \\
\hline $\begin{array}{l}\text { Audit Type- Non-Big } \\
4 * *\end{array}$ & 30 & 0.00 & 3.98 & 301 & 0.73 \\
\hline TobinQ (Growth) & 71 & .02 & 3.16 & 1.33 & .61 \\
\hline Profitability & 71 & 0.01 & 0.93 & 0.32 & 0.24 \\
\hline Firm size* & 71 & 7 & 21 & 13.19 & 2.09 \\
\hline Dividends Payout & 71 & 0.00 & 0.96 & 0.26 & 0.27 \\
\hline
\end{tabular}

* Firm's size is measured by the natural logarithm of sales in the regression model used in this study.

**No significant difference was found, using a Mann-Whitney test, between the mean of the Tobin Q in firms engaging with Big 4 and firms engaging with other auditing firms. 
Table 4: Model Summary

\begin{tabular}{|c|c|c|c|c|c|}
\hline $\mathbf{R}$ & R Square & $\begin{array}{c}\text { Adjusted R } \\
\text { Square }\end{array}$ & F & p-value & Durbin-Watson \\
\hline .56 & .32 & .18 & 2.35 & .036 & 2.06 \\
\hline
\end{tabular}

Table 5: The results of the regression model

\begin{tabular}{|c|c|c|c|c|c|c|}
\hline Descriptions & $\begin{array}{c}\text { Expected } \\
\text { Sign }\end{array}$ & Coefficients & \multicolumn{2}{|c|}{ Sig. } & \multicolumn{2}{c|}{ Collinearity Statistics } \\
\hline & & B & $t$ & $P$-value & Tolerance & VIF \\
\hline (Constant) & & -.968 & -1.254 & .217 & & \\
\hline Board Size & - & -.054 & -1.480 & .147 & .884 & 1.131 \\
\hline Institutional Investors & + & -.008 & -2.259 & .029 & .754 & 1.327 \\
\hline Governmental ownership & + & -.002 & -.420 & .677 & .898 & 1.114 \\
\hline Audit Type & + & -.065 & -.446 & .658 & .894 & 1.119 \\
\hline ToninQ (Growth) & + & .007 & .059 & .953 & .940 & 1.064 \\
\hline Profitability & - & -.268 & -1.376 & .176 & .803 & 1.245 \\
\hline Firm Size & + & .160 & 3.366 & .002 & .642 & 1.557 \\
\hline Dividend Payout & - & -.002 & -2.884 & .006 & .633 & 1.579 \\
\hline
\end{tabular}

